\title{
Generisk ordinering av medikamenter i sykehus
}

\author{
Universitetssykehuset Nord-Norge innførte i februar 2012 virkestofforskrivning av medikamenter til inne- \\ liggende pasienter. Lege ordinerer legemidlets generiske navn og sykepleier dokumenterer handelsnavnet \\ til preparatet som blir gitt. Vi mener at ordningen gjør det lettere å oppdage forveksling av medikamenter \\ med likelydende navn og at risikoen for ordinering av to legemidler med samme virkestoff reduseres.
}

Antall medikamenter og synonympreparater har økt de siste årene. Allerede i 2001 ble generisk legemiddelbytte innført på apotek (1). Ulike apotek velger ulikt synonympreparat med bakgrunn i ulike prisavtaler, slik at pasientene ofte ikke bruker samme preparat over tid. I 2010 ble generisk ordinering innført for enkelte avdelinger ved Universitetssykehuset NordNorge, og fra februar 2012 ble slik ordinering innført i hele sykehuset. Så vidt oss bekjent er sykehuset det eneste i Norge der legene ordinerer medikamenter med generisk navn. Vi tror at våre erfaringer kan være av interesse for andre sykehus som vurderer å innføre generisk ordinering, og redegjør her for bakgrunnen for endringen og for prosessen rundt implementeringen.

\section{Antatte fordeler}

Det er en utfordring for legene å holde oversikt over handelsnavnene, og vi har sett at dobbeltordinering av medikamenter med ulike handelsnavn og samme virkestoff forekommer. Dessuten brukes det mye ressurser til «oversetting» mellom handelsnavn og generiske navn ved inn- og utskrivning av sykehus og hver gang sykepleier foretar generisk bytte ved istandgjøring av medikamenter til innlagte pasienter.

Tidligere ordinerte leger ved Universitetssykehuset Nord-Norge medikamenter med handelsnavn på medisinkurven. Sykepleier utførte generiske bytter til de preparatene som var tilgjengelig på avdelingen. Byttene ble utført på nytt ved hver istandgjøring, og sykepleierne dokumenterte ikke i medisinkurve eller journal hvilket preparat det ble byttet til. Når medikamentet ordineres med generisk navn, kan sykepleieren kontrollere at det generiske navnet som er ordinert er det samme som står på legemiddelpakningen. Forveksling av både generiske navn og handelsnavn forekommer, men vil trolig lettere bli oppdaget når begge navnene står ved siden av hverandre på medisinkurven (2), slik de gjør etter innføring av generisk ordinering ved vårt sykehus.

Sist, men ikke minst: Generiske navn er en del av det felles medisinske fagspråket for helsepersonell verden over. Gjennomgående bruk av generiske navn vil trolig lette kommunikasjonen med kolleger utdannet $\mathrm{i}$ ulike land.

\section{Forberedelser}

Overgangen til generisk ordinering ble forberedt i tett samarbeid mellom sykehusets kvalitetsavdeling, sykehusapotek og sengepostene. Medisinkurver ble tilpasset og prosedyren for føring av medisinkurve ble oppdatert og gjort gjeldende i hele sykehuset (3). Det ble utarbeidet en skriftlig prosedyre for generisk ordinering: preparatets generiske navn, styrke, legemiddelform, administrasjonsmåte og dosering skal angis og type tabletter, f.eks. depottabletter eller sugetabletter, skal spesifiseres. Dersom

\section{«Generiske navn}

\section{er en del av det felles medisinske fagspråket for helsepersonell \\ verden over»}

legemidlet består av tre eller flere virkestoff, har begrenset byttbarhet eller ikke egner seg for generisk bytte, kan legemidlet ordineres med sitt handelsnavn (3). I avdelinger som skriver ut medisinkurver fra medikamentmodulen i den elektroniske pasientjournalen, legger dataprogrammet til det generiske navnet når legen skriver handelsnavn. Sykepleierne dokumenterer handelsnavnet til preparatet som blir gitt i en egen kolonne i medisinkurven (3).

Sykehusapoteket har laget en elektronisk «bytteliste» som gir oversikt over byttbare preparater. Listen oppdateres kontinuerlig og den er lett tilgjengelig fra den elektroniske pasientjournalen.

Medikamentoversikten i epikrisen ble endret slik at generiske navn føres i tillegg til handelsnavn (3). Vi tror det gjør det enklere for pasienten å holde oversikt over medikamenter med ulike handelsnavn etter utreise.

Avdelingene oppnevnte «apotekkontakter» som fungerte som bindeledd mellom avdelingen og sykehusapoteket. Det ble holdt undervisningsmøter for apotekkontaktene, og sykehusapoteket gjennomførte avdelingsvise undervisningsmøter med en film som utgangspunkt (3). Sykehusfarmasøytene tilbød også undervisning i føring av de nye medisinkurvene.

\section{Oppfølging}

Kurveføringen er fulgt opp med stikkprøver og tre mer omfattende kartlegginger én, seks og 12 måneder etter innføringen i 2012.

Ett år etter innføringen var handelsnavnet dokumentert for $88 \%$ av undersøkte ordinasjoner i psykiatriske avdelinger og $77 \%$ i somatiske avdelinger ved Universitetssykehuset Nord-Norge, Tromsø (3). Den største bekymringen er knyttet til manglende ordinering av «legemiddelform» i somatiske avdelinger, spesielt der hastigheten på frisettingen av virkestoffet varierer i ulike formuleringer. Fire legemiddelfeil som skyldtes at man ikke hadde brukt «byttelisten», er blitt meldt som avvik (O. Moe, Kvalitetsavdelingen, Universitetssykehuset Nord-Norge, personlig meddelelse).

Sykehusfarmasøytene har i mange år hatt tilsyn med kurveføringen. Selv om tidligere funn ikke er kartlagt etter samme mal, er inntrykket at det ikke er flere legemiddelfeil og heller ikke nye typer legemiddelfeil etter innføringen av generisk ordinering. Ordinering av legemiddelform er avgjørende for valg av riktig preparat ved generisk ordinering, og sykehusfarmasøytene har fokus på det $\mathrm{i}$ undervisning for legene. Kartleggingen tyder på at kurveføringen var mer fullstendig tidlig etter innføringen enn etter ett år (3). Det blir derfor viktig å følge opp kurveføringen fremover og gi opplæring ved behov.

Tilpasningen av medisinkurven har vært en utfordring. Fordi kolonnen for «generisk navn» måtte legges til, ble antall døgn kurven kan brukes redusert fra åtte til fem. Dette vil kunne løses bedre i en elektronisk medisinkurve. Her vil det også være muligheter for beslutningsstøtte og for å sperre for lagring av ufullstendige ordinasjoner.

\footnotetext{
Margitta T. Kampman

margitta.kampman@unn.no

Nina Merete Bjæring Brox

Einar Bugge

Camilla Bjørnstad
} 
Margitta T. Kampman (f. 1962) er overlege ved Nevrologisk avdeling, Universitetssykehuset Nord-Norge.

Forfatter har fylt ut ICMJE-skjemaet og oppgir ingen interessekonflikter.

Nina Merete Bjæring Brox (f.1972) er avdelingsleder og rådgivningsfarmasøyt ved Sykehusapoteket i Troms $\varnothing$.

Forfatter har fylt ut ICMJE-skjemaet og oppgir ingen interessekonflikter.

Einar Bugge (f. 1963) er lege ved Fag- og forskningssenteret, Universitetssykehuset NordNorge.

Forfatter har fylt ut ICMJE-skjemaet og oppgir ingen interessekonflikter.

Camilla Bjørnstad (f. 1975) er apoteker ved Sykehusapoteket i Troms $\varnothing$.

Forfatter har fylt ut ICMJE-skjemaet og oppgir ingen interessekonflikter.

\section{Litteratur}

1. Ot.prp. nr. 16 (2002-2003). Om lov om endringer i legemiddelloven og apotekloven. 2.3 Generisk bytte i apotek. www.regjeringen.no/nb/dep/

hod/dok/regpubl/otprp/20022003/otprp-nr-162002-2003-/2/3.html?id=171098 (12.2.2014).

2. Hoffman JM. Proulx SM. Medication errors caused by confusion of drug names. Drug Saf 2003; 26: 445-52.

3. Universitetssykehuset Nord-Norge. Generisk ordinering. www.unn.no/generisk-ordinering/ category34559.html (12.2.2014).

Mottatt 30.11. 2013, første revisjon innsendt 17.1. 2014, godkjent 14.2. 2014. Redaktør: Siri Lunde Strømme.

Publisert først på nett. 